the past quarter of a century. Various bodies interested in sandal are collaborating, such as the Madras Forest Department, the Indian Institute of Science at Bangalore, the Forest Research Institute at Dehra Dun and others. A report on the progress made during the half-year ending September 30,1932 , entitled "Investigations on the SpikeDisease of Sandal" has been issued by the Institute of Science, Bangalore. The sporadic attacks of this pest have a strange parallel to those of foot and mouth disease in Great Britain. A recrudescence of the disease in an epidemic form has been noticed in the Beedamaruthupatti spike area. Pollarding, which has been carried out on a fairly large scale in the Galigattam and Manchi areas, has yielded significant data. So far, Manchi has the maximum percentage of disease-masking sandal plants. The entire freedom from infection of a few areas, Sanamavu and Thalli in North Salem and Chickabettakere in Coorg, has been established by pollarding. More detailed technical contributions will appear as scientific papers in the Journal of the Indian Institute of Science, Dehra Dun Forest Research Publications, and elsewhere. Meanwhile it is a valuable departure to issue progress reports so that the various investigators studying the pest, which causes so heavy a financial loss, should have early news of any results achieved.

\section{Poison Control and its Effect upon Wild Life}

IN California the control of the ground squirrel (Citellus beecheyi) by poison has given rise to strong protests in journals devoted to ornithology and bird protection, on account of the death by poisoning of numbers of wild creatures which are not injurious. We have already referred to some of these articles, and in fairness, it ought to be stated that the California Department of Agriculture, which is responsible for the organisation of the poisoning measures, accepts neither the "facts" nor the conclusions of the writers. In a summary of "The California Ground Squirrel Control Program", Eugene S. Kellogg states that those in charge of rodent operations were anxious to know what effect thallium, exposed on bait for ground squirrels, might have on other species of wild life, or how it might act as a secondary poison on predatory animals and birds. To check this point, the Biological Survey made a careful census of the wild life, then exposed baits far heavier than necessary for existing ground squirrel population in order to learn wild life tolerances. Careful checking by several observers during thirty days failed to show an appreciable effect on the beneficial animal life of the area. Hawks, quail and mourning doves, the species watched most carefully, appeared to be as numerous at the conclusion of the test as before (California Dept. Agr. Special Pub. No. 109). In this clash of opinion it is impossible for the outsider to discover exactly where the truth lies; our impression is that there is a certain amount of bias on each side and an absence of the scientific detachment which would carry conviction. A basic fact which cannot be ignored is that ground squirrels are an economic pest which somehow must be controlled.

\section{Smithsonian Field Expeditions in 1932}

NoNE of the many-sided activities of the Smithsonian Institute appeals so much to the imagination as the explorations and field work. During 1932, twenty-five expeditions were sent out or participated in for research in anthropology, biology, geology and astrophysics. These expeditions visited thirteen States of the United States, Europe, Canada, Alaska, Mexico, Hispanola, Jamaica, British Guiana and South-West Africa. Amongst the more interesting were a trip to various mining localities in Mexico for the collection of certain rare minerals and ores, a bird-collecting expedition to Hispanola, and a continuation of anthropological work in Alaska, where the characteristics of the living natives were studied, and the skeletal and archæological relics of an earlier civilisation were unearthed by excavation. The reduction in the Institute's income, both private and governmental, has occasioned strict economy in all lines and curtailment of some activities. Funds for publication have been cut nearly to one-half of the previous year's amount, with the result that valuable manuscripts have had to be refused or held up for a year, and the annual report, from which we have quoted above, has itself been cut to half its normal size. If the economies which must be enforced in other countries as well as in the United States, lead to the condensation of the published records of scientific work in some cases, and in other cases to more rigorous selection for publication, the experience will not be altogether wasted.

\section{Agricultural History in Germany}

The Agricultural History Society of America, referred to in NATURE of March 19, 1932, p. 432, has a German counterpart in the Gesellschaft für Geschichte und Literatur der Landwirtschaft. Membership of this society is open to all persons interested, the subscription for persons resident outside Germany being $4 \mathrm{RM}$. per annum. The society's inquiries are not confined to central Europe. Investigation of the history of prominent agriculturists and of farms that have been in long-eontinued ownership by one family are noteworthy aspects of its activity. It publishes a small quarterly (free to members) containing articles, reviews and a list of current books and papers. Recent issues have included articles on the measures devoted to the development of Chinese agriculture under the Mongols, the Swiss Peasant Association, and the use of marl in ancient and medieval times. Information regarding the society can be obtained from Prof. W. Seedorf, Gosslerstrasse 16, Göttingen, Germany.

\section{New Record for Deep Drilling}

THE issue of the Oil Weekly of May 1 gives details of the establishment of a new depth record of 10,668 ft. for oil-well drilling, which has been achieved on the Kettleman Hills Field, California. This depth exceeds the previous record by $83 \mathrm{ft}$. The well has been drilled with standard rotary equipment and, so far, a $5 \frac{5}{8}$ in. hole is being made. It is destined to 